\title{
Pengaruh Temperatur dan Lama Thawing terhadap Kualitas Spermatozoa Sapi dalam Penyimpanan Straw Beku
}

\author{
S. Utomo dan E. Boquifai \\ Jurusan Peternakan, Fakultas Pertanian Universitas Mercu Buana, Yogyalarta
}

\begin{abstract}
ABSTRAK
Penelitian bertujuan untuk mengetahui pengaruh temperatur dan lama thawing terhadap kualitas spermatozoa yang disimpan beku dalam ministraw. Sebanyak 75 ministraw beku sperma sapi bangsa Simental dithawing dengan air yang bersuhu $5^{\circ} \mathrm{C}, 26^{\circ} \mathrm{C}$ dan $37^{\circ} \mathrm{C}$ selama $5,10,15,20$ dan 30 detik. Kualitas spermatozoa pasca thawing ditentukan berdasarkan derajad keasaman (pH) dan gerak individu (motilitas) spermatozoa. Rancangan yang digunakan adalah Rancangan Acak Lengkap pola faktorial 3X5, analisis data menggunakan analisis variansi dan perbedaan antar perlakuan diuji lanjut dengan DMRT. Hasil penelitian menunjukkan bahwa motilitas spermatozoa yang dithawing pada suhu $37^{\circ} \mathrm{C}$ lebih baik jika dibandingkan dengan tempertur lainnya. Temperatur dan lama thawing tidak berpengaruh terhadap $\mathrm{pH}$ dan motilitas spermatozoa. Sebaiknya thawing dilakukan pada temperatur $37^{\circ} \mathrm{C}$ dengan lama thawing 15 detik.
\end{abstract}

Kata kunci : Thawing, spermatozoa, ministraw, semen beku

\section{The Effect of Temperture and Thawing Duration of Frozen Semen in Ministraw on Sperm Quality}

\section{ABSTRACT}

This research was conducted to investigate the effect of temperature and duration of thawing frozen semen in ministraw on quality sperm. Seventy five ministraws frozen semen of Simmental breed were thawing by water with temperature 5, 26 and $37^{\circ} \mathrm{C}$, with duration of 5,10 , 15, 20 and 30 second. The quality sperm post thawing was measured based on $\mathrm{pH}$ and motility. The design of this research was completely randomized design with factorial clasification $3 \times 5$. The result showed that the motility of sperm was thawing $37^{\circ} \mathrm{C}$ better than the other temperature. The quality of sperm was no affected by temperature and duration of thawing. It could be concluded that thawing of frozen semen will have better done at $37^{\circ} \mathrm{C}$ with duration of 15 second.

Key words : Thawing, sperm, ministraw, frozen semen.

\section{PENDAHULUAN}

Inseminasi Buatan (IB) merupakan teknik perkawinan buatan untuk meningkatkan kualitas genetik ternak pada keturunannya. Teknik IB diprogramkan dalam pembangunan peternakan di Indonesia untuk dua tujuan sekaligus yaitu peningkatan mutu genetik ternak dan peningkatan populasi ternak. Dua tujuan ini diarahkan untuk mengatasi permasalahan rendahnya konsumsi protein hewani khususnya yang berasal dari ternak. Untuk mempercepat keberhasilan IB harus ditunjang melalui penggunaan semen beku. 
Semen beku yang umumnya digunakan oleh para inseminator di Indonesia adalah dalam bentuk ministraw, sehingga diharapkan tetap memiliki kualitas pembuahan yang optimal (Salisbury dan Van Demark, 1985). Salah satu penentu kualitas semen beku adalah teknik thawing yang digunakan oleh para inseminator di lapangan. Teknik thawing yang kurang tepat menyebabkan banyak sel semen yang mengalami penurunan kemampuan pembuahan. Di Jerman thawing dilakukan menggunakan air yang bertemperatur $34^{\circ} \mathrm{C}$ selama 15 detik, sedangkan di Amerika Serikat thawing biasanya dilakukan pada air es yang bertemperatur $5^{\circ} \mathrm{C}$ selama $5-6$ menit (Toelihere, 1993). Thawing pada air yang bertemperatur $38^{\circ} \mathrm{C}-40^{\circ} \mathrm{C}$ menghasilkan daya hidup yang lebih baik jika dibandingkan dengan temperatur lebih rendah (Toelihere, 1993). Salisbury dan Van Demark (1985) menyatakan bahwa thawing pada temperatur $5^{\circ} \mathrm{C}$ menghasilkan motilitas lebih baik jika dibandingkan dengan $38^{\circ} \mathrm{C}$. Karena belum ada keseragaman temperatur dan waktu thawing maka penelitian ini dilaksanakan untuk membuat pedoman thawing khususnya untuk wilayah Yogyakarta dan sekitarnya.

Penelitian ini dilaksanakan dengan tujuan untuk mencari temperatur dan lama thawing semen beku sapi dalam bentuk ministraw yang mampu menjamin kualitas spermatozoa. Sehingga diharapkan akan diketahui temperatur dan lama thawing yang paling tepat dapat dipedomani oleh para inseminator di lapangan.

\section{MATERI DAN METODE}

Bahan dalam penelitian ini adalah ministraw semen beku sebanyak 75 buah, air thawing yang bertemperatur $5^{\circ} \mathrm{C}, 26^{\circ} \mathrm{C}$ dan $37^{\circ} \mathrm{C}$. Sedangkan alat yang digunakan adalah peralatan laboratorium Semen Beku UPTD BPMBPT DIY untuk pemeriksaan kualitas semen.

Penelitian ini dilakukan terhadap ministraw semen beku 7 hari setelah prosesing. Perlakuan yang diterapkan meliputi :

* Perlakuan air thawing yang bertemperatur $5^{\circ} \mathrm{C}$ selama 5, 10. 15, 20 dan 30 detik

* Perlakuan air thawing yang bertemperatur $26^{\circ} \mathrm{C}$ selama 5, 10. 15, 20 dan 30 detik

* Perlakuan air thawing yang bertemperatur $37^{\circ} \mathrm{C}$ selama 5, 10. 15, 20 dan 30 detik

Masing-masing perlakuan dilakukan pengulangan sebanyak 5 kali. Parameter kualitas semen diamati adalah $\mathrm{pH}$ semen dan motilitas spermatozoa pasca thawing sesuai dengan perlakuan yang ada.

Penelitian dirancang dengan Rancangan Acak Lengkap (RAL) pola faktorial 3 X 5 . Data yang diperoleh dianalisis dengan analisis variansi dan perbedaan yang terjadi akan diuji lanjut dengan DMRT.

\section{HASIL DAN PEMBAHASAN}

\section{Ukuran Kualitas pH Semen}

Rerata $\mathrm{pH}$ semen pasca thawing berdasarkan temperatur $5^{\circ} \mathrm{C}, 26^{\circ} \mathrm{C}$ dan $37^{\circ} \mathrm{C}$ secara berurutan adalah 6,$85 ; 6,82$ dan 6,81 .

Tabel 1. Rerata $\mathrm{pH}$ semen pasca thawing berdasarkan temperatur dan lama Thawing

\begin{tabular}{lcccc}
\hline \hline \multirow{2}{*}{$\begin{array}{l}\text { Lama thawing } \\
\text { (detik) }\end{array}$} & \multicolumn{3}{c}{ Temperatur thawing } & \\
\cline { 2 - 4 } 5 & $5^{\circ} \mathrm{C}$ & $26^{\circ} \mathrm{C}$ & $37^{\circ} \mathrm{C}$ & Rerata \\
10 & 6,90 & 6,80 & 6,76 & 6,82 \\
15 & 6,72 & 6,86 & 6,80 & 6,79 \\
20 & 6,88 & 6,82 & 6,80 & 6,83 \\
30 & 6,84 & 6,82 & 6,82 & 6,82 \\
\hline Rerata & 6,92 & 6,80 & 6,90 & 6,87 \\
\hline
\end{tabular}


Sedangkan rerata $\mathrm{pH}$ semen pasca thawing berdasarkan lama waktu thawing 5, 10, 15, 20 dan 30 detik secara berurutan adalah 6,28; 6,79; 6,83; 6,82 dan 6,87 (Tabel 1).

Berdasarkan hasil analisis diketahui bahwa pH semen pada semua perlakuan temperatur thawing berbeda tidak nyata. Hal ini disebabkan karena pengukuran $\mathrm{pH}$ sampai dengan temperatur thawing $37^{\circ} \mathrm{C}$ dilakukan pada suhu ruang yang relatif sama. Akibatnya penimbunan asam laktat hasil metabolisme spermatozoa secara anaerob akan menghasilkan timbunan asam laktat yang relatif sama antar perlakuan. Sedangkan jika dilihat kisaran capaian $\mathrm{pH}$ semua perlakuan (Tabel 1) yaitu 6,81 - 6,85 berada pada kisaran normal semen (Toelihere, 1993).

Hasil analisis juga menunjukkan bahwa tidak terdapat interksi yang nyata antara temperatur dengan lama thawing terhadap $\mathrm{pH}$ semen. Hal ini disebabkan karena perubahan $\mathrm{pH}$ sangat dipengaruhi oleh adanya aktifitas metabolisme anaerob spermatozoa pasca thawing yang akan menghasilkan timbunan asam laktat relatif sama. Aktifitas pergerakan normal akan dicapai pada temperatur $37^{\circ} \mathrm{C}$ sebagaimana dalam saluran reproduksi betina (Partodihardjo, 1992). Perbedaan temperatur dan lama thawing belum berpengaruh terhadap perubahan $\mathrm{pH}$ semen. Aktifitas yang terjadi pasca thawing juga belum menghasilkan timbunan asam laktat yang cukup berarti antar perlakuan.

\section{Ukuran kualitas motilitas spermatozoa}

Rerata motilitas spermatozoa dari ministraw beku yang dithawing pada temperatur $5^{\circ} \mathrm{C}, 26^{\circ} \mathrm{C}$ dan $37^{\circ} \mathrm{C}$ berturut-turut adalah 41,12\%, 45,52\% dan 47,24\%. Sedangkan ukuran motilitas karena lama thawing 5, 10, 15, 20 dan 30 menit secara berturutan adalah 43,73\%, 43,73\%, 44,60\%, $45,13 \%$ dan $45,13 \%$. Selengkapnya adalah tertera pada Tabel 2 .

Hasil analisis menunjukkan bahwa temperatur thawing $5^{\circ} \mathrm{C}, 26^{\circ} \mathrm{C}$ dan $37^{\circ} \mathrm{C}$ berpengaruh nyata $(\mathrm{P}<0,05)$ terhadap ukuran kualitas motilitas spermatozoa. Perlakuan temperatur thawing $5^{\circ} \mathrm{C}$ secara signifikan berbeda nyata dengan $37^{\circ} \mathrm{C}$ namun tidak berbeda nyata dengan temperatur thawing $26^{\circ} \mathrm{C}$, hal ini disebabkan bahwa proses pencairan sebenarnya sudah dimulai semenjak dikeluarkan dari kontainer depo. Pengeluaran ministraw dari kontainer ini secara otomatis akan meningkatkan suhu (thawing alami) dari suhu beku menuju suhu ruang. Oleh karena suhu ruang di daerah Yogyakarta berkisar $26^{\circ} \mathrm{C}$ maka thawing $5^{\circ} \mathrm{C}$ dan $26^{\circ} \mathrm{C}$ sebenarnya sudah terjadi secara alami. Peningkatan motilitas secara signifikan terjadi pada temperatur $37^{\circ} \mathrm{C}$, sebagaimana disebutkan bahwa optimal motilitas oleh karena pengaruh suhu terjadi pada temperatur $37^{\circ} \mathrm{C}$ (Peters and Ball, 1995).

Pada temperatur $5^{\circ} \mathrm{C}$ dan $26^{\circ} \mathrm{C}$ terjadi aktifitas metabolisme yang belum optimal sehingga akan menyebabkan pergerakan individunyapun masih relatif terbatas. Sedangkan pada temperatur $37^{\circ} \mathrm{C}$ pergerakan dicapai optimal oleh karena energi yang dihasilkan oleh metabolisme juga secara maksimal. Thawing pada air yang bersuhu $37^{\circ} \mathrm{C}-38^{\circ} \mathrm{C}$ akan menghasilkan motilitas spermatozoa yang lebih baik dibanding suhu thawing yang lebih rendah. Proses metabolisme yang meningkat pada suhu $37^{\circ} \mathrm{C}$ tidak akan mengurangi substrat energi spermatozoa sehingga motilitas spermatozoa akan tinggi karena tidak kekurangan energi (Zenichiro et al. (2002).

Thawing dengan air yang bersuhu $37^{\circ} \mathrm{C}$ dapat membantu semen untuk melewati masa kritisnya dengan cepat karena suhu tersebut sama dengan temperatur tubuh ternak (Laing, 1970 dan Amin, $1999 . \quad$ Secara rata-rata thawing menggunakan suhu $5^{\circ} \mathrm{C}, 26^{\circ} \mathrm{C}$ dan $37^{\circ} \mathrm{C}$ adalah baik karena menghasilkan motilitas di atas $40 \%$ saat akan di IB kan sebagaimana Hafez (1993) yang mensyaratkan motilitas pasca thawing adalah $40-75 \%$ dan berdasarkan Laporan BIB Singosari (2004) yang menyatakan motilitas pasca thawing yang baik adalah harus di atas $40 \%$.

Ukuran kualitas motilitas spermatozoa 
Tabel 2. Rerata motilitas spermatozoa (\%) pasca thawing berdasarkan Perlakuan

\begin{tabular}{lcccc}
\hline \hline \multirow{2}{*}{$\begin{array}{l}\text { Lama Thawing } \\
\text { (detik) }\end{array}$} & \multicolumn{3}{c}{ Temperatur Thawing } & Rerata \\
\cline { 2 - 4 } & $5^{\circ} \mathrm{C}$ & $26^{\circ} \mathrm{C}$ & $37^{\circ} \mathrm{C}$ & 43,73 \\
5 & 40,20 & 45,00 & 46,00 & 43,73 \\
10 & 40,00 & 45,40 & 45,80 & 44,60 \\
15 & 38,80 & 46,00 & 49,00 & 45,13 \\
20 & 41,60 & 45,80 & 48,00 & 45,93 \\
30 & 45,00 & 45,40 & 47,40 & - \\
\hline Rerata & $41,12^{\mathrm{a}}$ & $45,52^{\mathrm{ab}}$ & $47,24^{\mathrm{b}}$ & \\
\hline
\end{tabular}

a,b,c Superskrip yang berbeda pada rerata menunjukkan perbedaan yang nyata $(\mathrm{P}<0,05)$.

tidak dipengaruhi oleh lama thawing dari 5, 10, 15, 20 dan 30 detik. Hal ini disebabkan karena pendeknya ukuran waktu thawing dibandingkan dengan reaksi metabolisme spermatozoa sebagaimana ketentuan Toelihere (1993) yang menyatakan bahwa thawing semen harus segera diinseminasikan dalam waktu yang tidak lebih dari 5 menit. Lama waktu thawing belum menimbulkan perubahan aktifitas pergerakan individu secara berarti antar perlakuan waktu tersebut disamping itu juga dinyatakan bahwa thawing akan menghasilkan motilitas yang baik jika dilakukan pada air yang bersuhu $37^{\circ} \mathrm{C}$ $38^{\circ} \mathrm{C}$ selama 15 sampai 30 detik (Anonimus, 2004).

Analisis data juga menunjukkan bahwa tidak ada interaksi yang nyata antara temperatur dan lama thawing terhadap motilitas spermatozoa. Hal ini disebabkan bahwa lama waktu thawing yang ditetapkan belum cukup memberikan pengaruh signifikan terhadap motilitas, sedangkan terhadap temperatur thawing kisaran $5^{\circ} \mathrm{C}, \quad 26^{\circ} \mathrm{C}$ merupakan temperatur alami yang pasti akan dilalui selama proses pencairan menuju aktifitas optimal yang akan dicapai hingga temperatur $37^{\circ} \mathrm{C}$.

\section{KESIMPULAN}

Temperatur thawing semen sapi yang terbaik adalah pada $37^{\circ} \mathrm{C}$ sedangkan lama thawing dapat dilakukan antara 5 sampai 30 detik.

\section{DAFTAR PUSTAKA}

Anonimus, 2004. Pelatihan Inseminator pada Sapiu dan Kerbau. BIB Singosari, Malang. Dirjen Bina Produksi Peternakan, Indonesia. Malang. Jawa Timur.

Anonimus, 2002. Instruksi Praktis Teknologi Prosesing Semen Beku pada Sapi. BIB Singosari, Malang. Dirjen Bina Produksi Peternakan, Indonesia. Malang. Jawa Timur.

Hafez, E.S.E., 1993. Spermatozoa and Seminal Plasm. In Reproduction In Farm Animals. Edited by Hafez, E.S.E. $6^{\text {th }}$ Ed. Lea and Febiger. Philadelphia.

Laing, J.A., Melrose, D.R., Dawson, D.R., 1970. Fertility and Infertility in Domestic Animals, $3^{\text {th }}$ ed. Baelliere Tindall and Cassel, London.

Partodihardjo, S., 1992. Ilmu Reproduksi Hewan. Mutiara Sumber Widya, Jakarta.

Peters, A.R. and P.J.H. Ball, 1995. Reproduction in Cattle. $2^{\text {nd }}$ ed.Blackwell Science Ltd.

Salysbury, G.W., dan N.L. VanDemark, 1985. Physiology of Reproduction and Artificial Insemination of Cattle. $2^{\text {nd }}$ ed. Diterjemahkan R. Djanuar, 1985. Cetakan 1, Gadjah Madha Univesity Press, Yogyakarta.

Toelihere, M.R., 1993. Inseminasi Buatan pada Ternak. Cetakan ke-3. Angkasa, Bandung.

Zenichiro,K., Herliante dan Sarastina, 2002. Instruksi Praktis Teknologi Prosesing Semen Beku pada Sapi. Jica-BIB Singosari, Malang 